Marcin Krajewski*

\title{
Optymalizacja kosztów zatrudnienia na przykładzie wybranych niepracowniczych tytułów ubezpieczenia społecznego
}

\begin{abstract}
The optimization of employment costs on the example of selected non-employee titles to social insurance: The paper provides an analysis of advantages and disadvantages of the optimization of employment costs in Poland. The Polish Social Insurance Act introduced a model of autonomous burdens for different insurance titles based on three basic assumptions: full protection of employees, right to insurance, and flexibility in case of non-employee insurance titles. The choice of a form of employment determines the future benefits. The amount of contributions also affects the Social Insurance Fund's and National Health Fund's revenues. The author claims that optimization of employment costs creates the rationale for amending the current regulations. The article concludes with possible implications of the current model for employees, contractors, self-employed persons, and farmers.
\end{abstract}

Słowa kluczowe: $\quad$ ubezpieczenie społeczne, ubezpieczenie emerytalne, zleceniobiorca, umowa o pracę, umowa-zlecenie

Keywords: social insurance, pension insurance, contractor, contract of employment, civil-law contract

* Doktor nauk prawnych, adiunkt w Katedrze Prawa Pracy, Wydział Prawa i Administracji, Uniwersytet Łódzki • e-mail: marcin.krajewski@wpia.uni.lodz.pl • https://orcid.org/oooo-0002-8869-0362

\section{Uwagi wstępne}

Składki na ubezpieczenia społeczne i zdrowotne stanowią jeden z elementów determinujących wybór podstawy zatrudnienia. Poza składkami na wybór podstawy zatrudnienia wpływ wywierają m.in: wysokość wynagrodzenia, model opodatkowania przychodów, pozostałe składki i opłaty związane z zatrudnieniem, elastyczność regulacji zawartych w Kodeksie pracy ${ }^{1}$ (w szczególności w zakresie

1 Ustawa z 26 czerwca 1974 r. - Kodeks pracy, t.j. Dz.U. 2019, poz. 1040, ze zm. 
czasu pracy, trwałości stosunku pracy)2, zatrudnienie tymczasowe, a ponadto ulgi i preferencje związane z prowadzeniem działalności gospodarczej. Obecny model ubezpieczeń społecznych uzależnia podleganie ubezpieczeniom (w tym także: ustalanie podstawy wymiaru składki na ubezpieczenie czy zasady kumulacji tytułów ubezpieczenia) od posiadanego tytułu ubezpieczenia. W efekcie koszty zatrudnienia pracownika, zleceniobiorcy oraz osoby prowadzącej działalność pozarolniczą znacznie się różnią. Przypisanie wysokości składki do tytułu ubezpieczenia, a także brak bezwzględnej kumulacji wszystkich tytułów ubezpieczenia, pozwalają postawić hipotezę, że polski system ubezpieczeń społecznych cechuje elastyczność podlegania ubezpieczeniom. Ocena funkcjonującego modelu ubezpieczeń społecznych i ubezpieczenia zdrowotnego jest istotna, gdyż wraz z innymi elementami kreującymi wybór podstawy zatrudnienia pozwala określić podatność danego systemu prawnego na optymalizację oraz wyznaczyć jej ustawowe granice. Pod pojęciem optymalizacji rozumiem poszukiwanie najlepszego, ze względu na wybrane kryterium, rozwiązania danego zagadnienia gospodarczego, przy uwzględnieniu określonych przepisami prawa ograniczeń ${ }^{3}$. Formami optymalizacji w ubezpieczeniach społecznych będą m.in. możliwość wyboru oraz zmiany tytułu ubezpieczenia, co umożliwia zarówno podwyższenie, jak i obniżenie wysokości składki, czy też możliwość zadeklarowania wyższej składki niż minimalna, a tym samym nabycia świadczeń w wyższej wysokości.

Z uwagi na rozległość materii przedmiot artykułu ograniczono do niepracowniczych form aktywności zarobkowej objętych ubezpieczeniem społecznym. Poszczególne wątki koncentrują się na: wyborze tytułu podlegania ubezpieczeniom społecznym, zasadach ustalania składki na ubezpieczenie społeczne oraz wpływie optymalizacji na przychody Funduszu Ubezpieczeń Społecznych (FUS). W opracowaniu pominięto umowę o dzieło, która nie stanowi odrębnego tytułu ubezpieczenia społecznego i zdrowotnego. Warto jednak nadmienić, że z uwagi na wyłączenie tej umowy z zakresu podmiotowego ubezpieczenia społecznego i zdrowotnego należy ona do źródeł optymalizacji obciążeń. Wielość zagadnień związanych z zatrudnianiem na podstawie umowy o dzieło przemawia za przedstawieniem ich w odrębnym opracowaniu.

\section{Kierunki ewolucji wybranych tytułów ubezpieczenia na gruncie ustawy o systemie ubezpieczeń społecznych}

Ustawa o systemie ubezpieczeń społecznych ${ }^{4}$ wprowadziła jednolity model ochrony ryzyk socjalnych. Zastąpiła ona inne odrębne regulacje obejmujące

2 W. Muszalski, Czynniki prawa pracy ograniczające zatrudnienie - problem dyskusyjny, „Praca i Zabezpieczenie Społeczne” 2008, nr 12, s. 14.

3 Https://sjp.pwn.pl/szukaj/optymalizacja.html [dostęp: 1 marca 2019 r.].

4 Ustawa z 13 października 1998 r. o systemie ubezpieczeń społecznych, t.j. Dz.U. 2019, poz. 300 , ze zm.; dalej: ustawa o systemie. 
ubezpieczenie m.in. pracowników, zleceniobiorców czy też osób prowadzących działalność gospodarczą. W piśmiennictwie wskazuje się, że ustawa ta ma w pewnym zakresie charakter kodyfikacyjny ${ }^{5}$. Autorzy reformy nie przesądzali o docelowym modelu ubezpieczenia społecznego, co miało umożliwić przeprowadzanie kolejnych zmian dostosowujących to ubezpieczenie do zmieniających się uwarunkowań społecznych i gospodarczych, ale jednocześnie nie sprzyjało stabilności systemu ${ }^{6}$. Wdrożenie reformy systemu ubezpieczeń społecznych wiązało się przede wszystkim z podziałem zagregowanej składki finansowanej przez płatnika. W zreformowanym systemie ciężarem składki obciążono podmiot zatrudniający i osoby zatrudnione, zgodnie z zasadą symetrii zobowiązań ${ }^{7}$. Charakterystyczną cechą systemu ubezpieczeń stało się także dotowanie funduszy ubezpieczeniowych $\mathrm{z}$ budżetu państwa ${ }^{8}$. Dopłaty z budżetu państwa uzupełniają wypłatę świadczeń gwarantowanych, jeżeli przychody FUS nie zapewniają terminowej wypłaty świadczeń9.

Mimo wprowadzenia jednolitych zasad ubezpieczenia, w tym stóp procentowych składki ${ }^{10}$, ustawodawca zachował odrębne zasady ustalania podstawy wymiaru składek dla poszczególnych tytułów ubezpieczenia. Poziom obciążeń jest zatem zróżnicowany i przypisany do podstawy zatrudnienia. Przyjęty model autonomicznych obciążeń umożliwia realizację podstawowych założeń reformy: szczególnej ochrony pracowników, obowiązku ubezpieczenia z co najmniej jednego tytułu oraz względnej elastyczności ubezpieczenia w przypadku niepracowniczych tytułów ubezpieczenia. $Z$ drugiej strony wprowadzenie autonomicznych obciążeń oznacza możliwość poszukiwania rozwiązań minimalizujących wysokość składek na ubezpieczenia społeczne i zdrowotne. Działania te prowadzą do uszczuplenia przychodów FUS i NFZ (Narodowego Funduszu Zdrowia), a ponadto do obniżenia stopy zastąpienia dochodów przyszłym świadczeniem, co ma miejsce w przypadku zastępowania zatrudnienia pracowniczego - cywilnoprawnym czy zastępowania stosunku pracy - samozatrudnieniem zależnym. W celu ochrony stabilności finansowej obu systemów, ustawodawca wprowadzał kolejne nowelizacje obowiązujących przepisów, mające na celu: zmniejszenie dysproporcji obciążeń poszczególnych tytułów ubezpieczenia (szczególnie w relacji pracownik-zleceniobiorca), a także objęcie ubezpieczeniem kolejnych form aktywności zarobkowej.

5 U. Kalina-Prasznic, Uwagi na temat reformy ubezpieczenia społecznego pracowników, „Praca i Zabezpieczenie Społeczne” 1999, nr 1, s. 6.

${ }^{6}$ M. Rymsza, Docelowy model ubezpieczeń społecznych w Polsce, „Praca i Zabezpieczenie Społeczne" 1998, nr 9, s. 8.

7 Ibidem, s. 3.

8 K. Antonów, Finansowe aspekty ubezpieczeń, „Praca i Zabezpieczenie Społeczne” 2002, nr 11, s. 2.

9 Ibidem, s. 5.

${ }^{10} \mathrm{Z}$ wyjątkiem składki na ubezpieczenie $\mathrm{z}$ tytułu wypadków przy pracy i chorób zawodowych, która jest ustalana indywidualnie. 
Pochodną szczególnej ochrony pracowników stanowi przyjęcie przychodu jako podstawy wymiaru składki z tytułu stosunku pracy, a także bezwzględna kumulacja wybranych tytułów ubezpieczenia (np. stosunku pracy) ${ }^{11}$. Kumulacja tytułów, a tym samym i składek, jest istotna, gdyż w wyniku reformy systemu ubezpieczeń społecznych ograniczono redystrybucję składek emerytalnej i rentowej na rzecz silnej korelacji opłacanej przez płatnika składki i wypłacanego ubezpieczonemu świadczenia. W efekcie wysokość świadczeń, zarówno krótko- jak i długoterminowych, zapewnia osobom pozostającym w stosunku pracy najwyższą stopę zastąpienia spośród wszystkich tytułów objętych ubezpieczeniem. Zasada obowiązku ubezpieczenia z co najmniej jednego tytułu ubezpieczenia stanowi pochodną zasady powszechności oraz przymusu ubezpieczenia. Reformując system ubezpieczeń, ustawodawca objął obowiązkiem ubezpieczenia zróżnicowane formy aktywności zarobkowej (duchowni, nakładcy czy stypendyści sportowi). Rozbudowany zakres podmiotowy ustawy ma na celu nie tylko zwiększenie przychodów FUS i NFZ, ale umożliwia także znaczne zmniejszenie liczby osób nieubezpieczonych, co pozwala ograniczyć wydatki innych systemów, np. pomocy społecznej. Od roku 2013 dobrowolnym ubezpieczeniem emerytalnym i rentowym objęte zostały osoby, które nie spełniały warunków do objęcia tymi ubezpieczeniami obowiązkowo (np. zatrudnieni na podstawie umowy o dzieło). Zasada elastyczności ubezpieczenia jest powiązana z możliwością kumulowania kilku tytułów ubezpieczenia niepracowniczego $^{12}$. Strony umowy-zlecenia, umowy o pracę nakładczą, a także osoby prowadzące pozarolniczą działalność mają co do zasady możliwość wyboru tytułu (tytułów), z których ubezpieczony będzie podlegał ubezpieczeniu społecznemu ${ }^{13}$. Wyjątki, obejmujące zbieg tytułu pozarolniczej działalności z umową-zlecenia, pracą nakładczą oraz statusem osoby duchownej, przewidziano w art. 9 ustawy o systemie. Przepisy umożliwiają też zadeklarowanie podstawy wymiaru składki wyższej niż minimalna, niezależnie od osiągnię-

${ }^{11}$ Zgodnie $\mathrm{z}$ art. 9 ust. 1 ustawy o systemie bez względu na inne tytuły ubezpieczenia obowiązek ubezpieczenia powstaje z: tytułu stosunku pracy, umowy agencyjnej, umowy-zlecenia lub innej umowy o świadczenie usług, do której zgodnie z Kodeksem cywilnym stosuje się przepisy dotyczące zlecenia, albo umowy o dzieło, jeżeli umowę taką osoby zawarły z pracodawcą, z którym pozostają w stosunku pracy, lub jeżeli w ramach takiej umowy wykonują pracę na rzecz pracodawcy, z którym pozostają w stosunku pracy, członkostwa w spółdzielni, otrzymywania stypendium doktoranckiego, służby, pobierania świadczenia szkoleniowego, świadczenia socjalnego, zasiłku socjalnego albo wynagrodzenia przysługującego w okresie korzystania ze świadczenia górniczego lub w okresie korzystania ze stypendium na przekwalifikowanie.

12 T. Bińczycka-Majewska, Kumulacja i rozłączność tytułów ubezpieczenia społecznego, „Praca i Zabezpieczenie Społeczne” 2007, nr 1, s. 16-23.

${ }^{13}$ Szerzej o zbiegu tytułów zob. T. Bińczycka-Majewska, Zbieg tytułów ubezpieczenia emerytalnego i rentowego w nowym systemie ubezpieczeń społecznych, „Praca i Zabezpieczenie Społeczne” 2000, nr 12, s. 2 i n.; Ustawa o systemie ubezpieczeń społecznych, red. B. Gudowska, J. Strusińska-Żukowska, CH Beck, Warszawa 2014. 
tego wyniku gospodarczego ${ }^{14}$. Ma to miejsce np. w przypadku działalności pozarolniczej czy dobrowolnego ubezpieczenia emerytalnego i rentowego na podstawie art. 7 ustawy o systemie.

W dniu wejścia w życie ustawy o systemie pracownicy stanowili najliczniejszą grupę osób objętych ubezpieczeniem ${ }^{15}$. $Z$ tego też względu przyjęto założenie, że ciężar finansowania i wypłacalności systemu ubezpieczeń społecznych spoczywać będzie na pracodawcach oraz na pracownikach. Stabilność przychodów FUS, a także funduszy ubezpieczenia zdrowotnego, wymagała przewidywalności zarówno co do liczby ubezpieczonych, jak i osiągnięcia przez nich zgodnego z prognozami poziomu składki. Ustawodawca zadecydował więc o wyłączeniu elastyczności podlegania ubezpieczeniu społecznemu przez pracowników. Kolejne zmiany zasad podlegania ubezpieczeniom społecznym przez pracowników miały na celu:

- objęcie ubezpieczeniem zmultiplikowanych (zwielokrotnionych) tytułów ubezpieczenia,

- wprowadzenie obowiązku kumulowania składki z różnych tytułów ubezpieczenia aż do osiągnięcia minimalnego wynagrodzenia,

- uznanie za pracownika osoby wykonującej pracę na podstawie umowy agencyjnej, umowy-zlecenia lub innej umowy o świadczenie usług, do której zgodnie z Kodeksem cywilnym stosuje się przepisy dotyczące zlecenia, albo umowy o dzieło, jeżeli umowę taką zawarła z pracodawcą, z którym pozostaje w stosunku pracy, lub jeżeli w ramach takiej umowy wykonuje pracę na rzecz pracodawcy, $\mathrm{z}$ którym pozostaje $\mathrm{w}$ stosunku pracy.

Wobec nieelastycznej regulacji ubezpieczenia pracowniczego, na znaczeniu zyskała umowa-zlecenie, która do dziś stanowi podstawowe źródło optymalizacji obciążeń. Początkowo obowiązkiem ubezpieczenia objęto wyłącznie umowy agencyjne lub umowy-zlecenia zawarte na okres powyżej 14 dni. Zawierając taką umowę na okres krótszy, możliwe było całkowite wyłączenie zleceniobiorcy z ubezpieczenia. W celu uniknięcia obowiązku ubezpieczenia w miejsce zlecenia zawierano także nienazwane umowy o świadczenie usług. Tak ukształtowane umowy skutecznie konkurowały z zatrudnieniem pracowniczym. W celu przeciwdziałania zjawisku unikania ubezpieczenia nowelizacja z grudnia $1999 \mathrm{r}^{16}$

14 J. Stelina, Dobrowolne ubezpieczenie emerytalne [w:] Konstrukcje prawa emerytalnego, red. T. Bińczycka-Majewska, Zakamycze, Kraków 2004, s. 312.

15 W 1999 r. osoby pozostające w stosunku pracy stanowiły 80,4\% osób objętych ubezpieczeniem społecznym, ZUS, Rocznik statystyczny ubezpieczeń społecznych. System pozarolniczy 1999-2002, Warszawa 2004, tab. VII, s. 21. W 2014 r. osoby pozostające w stosunku pracy stanowiły $71,9 \%$ osób objętych ubezpieczeniem społecznym, ZUS, Rocznik statystyczny ubezpieczeń społecznych 2012-2014, Warszawa 2016, tab. VII, s. 34.

16 Ustawa z 23 grudnia 1999 r. o zmianie ustawy o systemie ubezpieczeń społecznych oraz niektórych innych ustaw, Dz.U. nr 110, poz. 1256. 
rozszerzyła obowiązek ubezpieczenia zleceniobiorcy o pozostałe umowy o świadczenie usług, do których zgodnie z Kodeksem cywilnym stosuje się przepisy dotyczące zlecenia. Zmianie uległy także zasady kumulacji kilku umów-zlecenia. Początkowo obowiązek ubezpieczenia obejmował wyłącznie jedną z umów, tj. zawartą najwcześniej lub wybraną przez strony umowy. Zgodnie z art. 18 ust. 3 ustawy o systemie w sytuacji, gdy odpłatność za wykonywanie takiej umowy określona została w kwotowej stawce godzinowej lub kwotowej stawce akordowej albo prowizyjnie (ostatnią z form dodano w powoływanej wcześniej nowelizacji z grudnia 1999 r.) podstawę wymiaru składki, podobnie jak w przypadku stosunku pracy, stanowił przychód. Dlatego też zleceniodawcy, próbując obniżyć podstawę wymiaru składki, zawierali w miejsce jednej - kilka umów. Każda z tak zawartych umów stanowiła odrębny tytuł do ubezpieczenia społecznego. Płatnicy składki dokonywali tym samym sztucznej multiplikacji, czyli zwielokrotnienia tytułów ubezpieczenia, dzięki której ubezpieczony podlegał obowiązkowemu ubezpieczeniu z jednej z zawartych umów. W 2016 r. na skutek kolejnej nowelizacji ustawy o systemie ${ }^{17}$, obowiązkiem ubezpieczenia objęto wszystkie umowy-zlecenia, aż do osiągnięcia podstawy wymiaru składki odpowiadającej wysokości minimalnego wynagrodzenia.

Na skutek działań optymalizacyjnych po stronie płatników licznym przeobrażeniom ulegał także tytuł działalności pozarolniczej. Pojęcie działalności pozarolniczej określone zostało w art. 8 ust. 6 ustawy o systemie. Pierwotnie ubezpieczeniem z tego tytułu objęto wyłącznie osoby wykonujące: pozarolniczą działalność gospodarczą, twórców i artystów oraz osoby wykonujące wolny zawód. W roku 2003 obowiązek ubezpieczenia rozszerzono o wspólników spółki jawnej, komandytowej lub partnerskiej, a także wspólnika jednoosobowej spółki z ograniczoną odpowiedzialnością ${ }^{18}$. Nowelizacja przepisów wynikała z faktu, że w miejsce np. spółki cywilnej czy jednoosobowej działalności gospodarczej przedsiębiorcy tworzyli nieobjęte ubezpieczeniem osobowe spółki prawa handlowego czy też jednoosobową spółkę z ograniczoną odpowiedzialnością. W 2009 r. ostatecznie ukształtowano pojęcie działalności pozarolniczej, obejmując obowiązkiem ubezpieczenia osobę prowadzącą niepubliczną szkołę, placówkę lub ich zespół na podstawie przepisów o systemie oświaty.

Równolegle do rozszerzania zakresu podmiotowego tytułu działalności pozarolniczej ustawodawca wprowadzał rozwiązania, których celem było obniżenie wysokości składek dla osób rozpoczynających prowadzenie działalności gospodarczej. Od 2005 r. osoby takie mają możliwość zadeklarowania obniżonej podstawy wymiaru składki przez okres 24 miesięcy. Minimalna jej wysokość

17 Ustawa z 23 października 2014 r. o zmianie ustawy o systemie ubezpieczeń społecznych oraz niektórych innych ustaw, Dz.U. poz. 1831.

18 A. Pędzierski, Zmiany w zakresie podlegania ubezpieczeniom społecznym i składek na ubezpieczenia, „Praca i Zabezpieczenie Społeczne” 2003, nr 5, s. 23. 
wynosi 30\% minimalnego wynagrodzenia w gospodarce narodowej. W $2018 \mathrm{r}$. wprowadzono zwolnienie z obowiązku ubezpieczenia osób fizycznych prowadzących działalność gospodarczą przez okres 6 miesięcy od dnia podjęcia takiej działalności, tzw. ulga na start ${ }^{19}$, czy też możliwość obniżenia podstawy wymiaru składki w przypadku osób wykonujących działalność gospodarczą na mniejszą skalę na podstawie art. 18c ustawy o systemie. Warto jednak zauważyć, że obniżenie składki do poziomu poniżej wynagrodzenia minimalnego skutkować będzie w przyszłości świadczeniami oscylującymi wokół minimum egzystencji. $Z$ tego też względu wprowadzane przepisy powinny zakładać wyłącznie czasowy charakter przyznanych ulg i zwolnień. Ograniczy to w przyszłości potrzebę uzupełniania świadczeń z ubezpieczenia społecznego z budżetu państwa.

Istotny problem stanowił także zbieg działalności gospodarczej oraz działalności rolniczej. Ustawa o ubezpieczeniu społecznym rolników ${ }^{20}$ wyłączała możliwość ubezpieczenia w KRUS przez osoby objęte ubezpieczeniem społecznym w ZUS. Wobec znacznej dysproporcji w wysokości składek rolnicy bądź nie podejmowali działalności gospodarczej, bądź też, naruszając obowiązujące przepisy, prowadzili taką działalność, nie zgłaszając jej do ewidencji (a tym samym do ubezpieczenia w ZUS). W 1997 r. wprowadzono możliwość wyboru między ubezpieczeniem w ZUS i KRUS. Osoba prowadząca działalność rolniczą, która rozpoczęła prowadzenie pozarolniczej działalności gospodarczej, zachowywała status rolnika, a tym samym miała możliwość uzyskania porównywalnego standardu socjalnego przy opłaceniu niemal dziesięciokrotnie niższej składki na ubezpieczenie społeczne ${ }^{21}$. Z uwagi na korzyści płynące $\mathrm{z}$ tego faktu w 1997 r. pozarolniczą działalność gospodarczą wykonywało 45,8 tys. osób ubezpieczonych w KRUS, a w 2003 r. - już 114,7 tys. osób objętych ubezpieczeniem społecznym rolników ${ }^{22}$. Nowelizacja ustawy o ubezpieczeniu społecznym rolników z $2004 \mathrm{r}^{23}$ wprowadziła roczną kwotę graniczną należnego podatku

19 Art. 18 ust. 1 ustawy z 6 marca 2018 r. - Prawo przedsiębiorców, Dz.U. 2019, poz. 1292, ze $\mathrm{zm}$.

20 Ustawa z 20 grudnia 1990 r. o ubezpieczeniu społecznym rolników, t.j. Dz.U. 2019, poz. 299.

${ }^{21}$ Miesięczna składka na ubezpieczenie społeczne rolników w I kwartale 2019 r. (łącznie z ubezpieczeniem chorobowym) wynosi 133 zł, a ubezpieczenie zdrowotne 1 zł z ha przeliczeniowego. Natomiast składka na ubezpieczenie osoby prowadzącej działalność pozarolniczą w ZUS w 2019 r. (łącznie z ubezpieczeniem chorobowym) wynosi 904, 60 zł, a na ubezpieczenie zdrowotne 342,32 zł, https://www.krus.gov.pl/krus/krus-w-liczbach/wymiar-kwartalnych-skladek-na-ubezpieczenie-spoleczne-rolnikow/; https://www.zus.pl/baza-wiedzy/ skladki-wskazniki-odsetki/skladki/wysokosc-skladek-na-ubezpieczenia-spoleczne [dostęp: 1 marca 2019 r.].

22 Https://www.krus.gov.pl/krus/krus-w-liczbach/liczba-osob-ubezpieczonych-w-kasie-prowadzacych-pozarolnicza-dzialalnosc-gospodarcza/ [dostęp: 1 marca 2019 r.].

23 Ustawa z 2 kwietnia 2004 r. o zmianie ustawy o ubezpieczeniu społecznym rolników oraz o zmianie niektórych innych ustaw, Dz.U. nr 91, poz. 873. 
dochodowego od przychodów z pozarolniczej działalności gospodarczej ${ }^{24}$, po przekroczeniu której rolnik albo zaprzestawał prowadzenia działalności gospodarczej i pozostawał w ubezpieczeniu w KRUS, albo też, prowadząc równolegle oba rodzaje działalności, podlegał wyłącznie ubezpieczeniu w ZUS. Taki stan rzeczy ograniczył migrację osób prowadzących działalność gospodarczą z ZUS do KRUS.

\section{Tytuł do ubezpieczenia a podstawa wymiaru składki na ubezpieczenie społeczne}

Model autonomicznych obciążeń poszczególnych tytułów ubezpieczenia różnicuje wysokość opłacanych składek. Pomimo uzyskania porównywalnego przychodu, składki opłacone za: pracownika, zleceniobiorcę oraz osobę prowadzącą pozarolniczą działalność będą znacznie się różnić. Ustawa o systemie przewiduje zasadniczo dwa progi, po osiągnięciu których następuje zwolnienie z obowiązku ubezpieczenia. Pierwszy to próg minimalnego wynagrodzenia. Jego osiągnięcie przez pracownika wyłącza obowiązek doubezpieczenia pozostałych (niepracowniczych) tytułów ubezpieczenia społecznego, zaś w przypadku zleceniobiorcy wyłącza obowiązek kumulacji kolejnych umów-zlecenia. Drugi to próg $60 \%$ przeciętnego wynagrodzenia w gospodarce narodowej. Wyznacza on minimalną możliwą do zadeklarowania składkę w przypadku osób prowadzących działalność pozarolniczą.

Osoba pozostająca w stosunku pracy jest objęta obowiązkowym ubezpieczeniem niezależnie od wysokości przychodu, wymiaru czasu pracy czy też liczby zawartych umów o pracę. W przypadku zbiegu stosunku pracy z pozostałymi tytułami ubezpieczenia ustawa o systemie przewiduje bezwzględne pierwszeństwo ubezpieczenia pracowniczego ${ }^{25}$. Podstawę wymiaru składki opłacanej za pracowników stanowi przychód. Jednocześnie w celu ograniczenia wysokości świadczeń wypłacanych przez ZUS ustawodawca wprowadził w art. 19 ust. 1 ustawy o systemie kwotę rocznego ograniczenia podstawy wymiaru składki emerytalnej i rentowej (w 2019 r. - 142950 zł) ${ }^{26}$. Od przychodów przekraczających tę kwotę płatnicy opłacają składkę wyłącznie na ubezpieczenie chorobowe i wypadkowe.

Z uwagi na nieelastyczne ujęcie ubezpieczenia pracowników na znaczeniu zyskują umowy-zlecenia, a także samozatrudnienie - umożliwiające minima-

${ }^{24}$ Zgodnie z obwieszczeniem Ministra Rolnictwa i Rozwoju Wsi z 19 kwietnia 2018 r. w sprawie rocznej kwoty granicznej (M.P. poz. 451) wysokość rocznej kwoty granicznej za rok 2018 wynosi 3376 zł.

${ }^{25}$ I. Jędrasik-Jankowska, Nowy system ubezpieczeń społecznych - wybrane problemy, „Praca i Zabezpieczenie Społeczne” 1999, nr 3, s. 19.

${ }^{26}$ Wynagrodzenie to jest określone w ustawie budżetowej, ustawie o prowizorium budżetowym lub ich projektach, jeżeli odpowiednie ustawy nie zostały uchwalone. 
lizację kosztów zatrudnienia ${ }^{27}$. Działania płatników, polegające na zawieraniu w miejsce umowy o pracę umów cywilnoprawnych, były przez długi czas kwestionowane przez ZUS. W piśmiennictwie oraz judykaturze dominuje pogląd, że o wyborze podstawy zatrudnienia decyduje co do zasady zgodna wola stron. Wybór podstawy zatrudnienia jest jednak ograniczony sposobem jej wykonywania oraz faktycznymi warunkami świadczenia pracy, które muszą odpowiadać szczególnym właściwościom charakterystycznym dla wybranego stosunku zatrudnienia ${ }^{28}$. Jednocześnie wolą stron nie można zmienić podstawy zatrudnienia wówczas, gdy sposób wykonywania przez pracownika czynności określonych umową wpisuje się w reżim art. $22 \$ 1$ Kodeksu pracy ${ }^{29}$. Na kształt orzeczeń sądów wpłynęły m.in. coraz liczniej występujące sytuacje, gdy zawarcie umowy cywilnoprawnej nie wynikało z przymusu ekonomicznego, a ze świadomego ukształtowania przez strony stosunku prawnego.

Zupełnie inną kwestię stanowi sytuacja najniżej zarabiających pracowników. Działalność pozarolnicza nie stanowi w ich przypadku źródła optymalizacji obciążeń, z uwagi na wysokość minimalnej możliwej do zadeklarowania składki z tytułu takiej działalności, odpowiadającej $60 \%$ przeciętnego wynagrodzenia $\mathrm{w}$ gospodarce narodowej. Często stosowaną formę minimalizacji kosztów zatrudnienia stanowiła multiplikacja tytułów ubezpieczenia (zawarcie z pracownikiem umów cywilnoprawnych). Z tego też względu ustawodawca rozszerzył obowiązek ubezpieczenia pracowników o: umowę o dzieło, umowę agencyjną, umowę-zlecenia lub inną umowę o świadczenie usług, do której zgodnie z Kodeksem cywilnym stosuje się przepisy dotyczące zlecenia, jeżeli taka umowa zawarta została z pracodawcą lub jeżeli w ramach takich umów wykonywano pracę na rzecz pracodawcy. $Z$ wykonywaniem czynności na rzecz pracodawcy wiążą się jednak kontrowersje, gdyż składka np. $z$ umowy o dzieło czy umowy-zlecenia jest opłacana przez pracodawcę, na rzecz którego takie usługi są świadczone, a nie przez podmiot będący stroną umowy cywilnoprawnej. To problematyczne rozwiązanie stanowiło wielokrotnie przedmiot orzeczeń Sądu Najwyższego ${ }^{30}$ oraz przedmiot badań naukowców ${ }^{31}$.

27 Szerzej zob. B. Więckowska, Źródła dochodów a składowanie na ubezpieczenia społeczne [w:] ZUS, Równowaga ekonomiczna systemów emerytalnych. Wspótpraca w ramach Unii Europejskiej w zakresie zabezpieczenia społecznego, Warszawa 2013, s. 97.

28 T. Duraj, Granice pomiędzy stosunkiem pracy a stosunkiem cywilnoprawnym - głos w dyskusji, „Gdańsko-Łódzkie Roczniki Prawa Pracy i Prawa Socjalnego” 2017, nr 7, s. 63 i n.

${ }^{29}$ Wyrok SN z 17 czerwca 2017 r., sygn. akt I PK 176/16, LEX nr 2300072.

${ }_{30}$ Uchwała SN z 2 września 2009 r., sygn. akt II UZP 6/09; wyrok SN z 7 lutego 2017 r., sygn. akt II UK 693/15.

${ }^{31}$ I. Jędrasik-Jankowska, Pojęcia i konstrukcje prawne ubezpieczenia społecznego, Wolters Kluwer Warszawa 2017, s. 88. Krytycznie o obowiązującej regulacji: M. Rylski, Pracodawca jako platnik składek za zleceniobiorców swego kontrahenta (art. 8 ust. 2 a ustawy o systemie), „Praca i Zabezpieczenie Społeczne” 2018, nr 3, s. 21. 
Kolejną metodę minimalizacji kosztów zatrudnienia stanowiło zawarcie umowy o pracę na część etatu i dodatkowo umowy-zlecenia z innym podmiotem niż pracodawca. W powoływanej już nowelizacji z grudnia 1999 r. ustawodawca wprowadził obowiązek kumulacji ubezpieczenia pracowniczego oraz innych tytułów ubezpieczenia w sytuacji, gdy podstawa wymiaru składek na ubezpieczenia emerytalne i rentowe z tytułów objętych zasadą bezwzględnego pierwszeństwa, m.in. ze stosunku pracy, jest niższa niż minimalne wynagrodzenie. Obowiązkowe doubezpieczenie obejmuje w takim wypadku zarówno umowy cywilnoprawne, jak i prowadzenie działalności gospodarczej. W ten sposób osiągnięte zostały dwa zasadnicze cele. Po pierwsze, ograniczono zasadność zawierania umowy o pracę na szczątkową część etatu, a po drugie, zagwarantowano ubezpieczonemu możliwość nabycia minimalnego świadczenia.

Jak już wspominano, umowa-zlecenie stanowi najczęściej wykorzystywane źródło optymalizacji obciążeń. Zgodnie $\mathrm{z}$ art. 18 ust. 3 i ust. 7 ustawy o systemie podstawę wymiaru składki z tego tytułu stanowi przychód albo zadeklarowana kwota, nie niższa niż minimalne wynagrodzenie. Druga z wymienionych metod ustalania podstawy wymiaru składki ze zlecenia znajdzie zastosowanie w sytuacji, gdy w umowie określono odpłatność za jej wykonywanie w sposób inny niż kwotowo, w kwotowej stawce godzinowej lub akordowej albo prowizyjnie. Zasadnicza różnica między zleceniem a umową o pracę będzie dotyczyła kumulacji kilku umów. W przypadku stosunku pracy ustawodawca nakazuje kumulację przychodu z każdej z zawartych umów, zaś w przypadku zlecenia obowiązkiem ubezpieczenia zostaje objęta co do zasady jedna z nich. Wybór kilku spośród pozostających w zbiegu umów-zlecenia umożliwia podwyższenie podstawy wymiaru składki na ubezpieczenia emerytalne i rentowe (a tym samym świadczeń np. emerytury czy renty). Podleganie ubezpieczeniu wyłącznie z jednej z zawartych umów oraz od podstawy odpowiadającej minimalnemu wynagrodzeniu oznacza $\mathrm{z}$ kolei niższe świadczenia $\mathrm{w}$ przyszłości. $\mathrm{Z}$ tego też względu ustawodawca obejmuje zleceniobiorców coraz szerszą ochroną, a sam status zleceniobiorcy w ubezpieczeniu coraz bardziej upodabnia się do statusu pracowników.

Z uwagi na szczególną pozycję przedsiębiorcy w prawie pracy jak i ubezpieczeniach społecznych od wielu lat tworzone są koncepcje dyferencjacji (uelastyczniania) obciążeń małych i średnich przedsiębiorstw. Działalność pozarolnicza stanowi ponadto źródło optymalizacji obciążeń oraz alternatywę dla pracowników posiadających wysokie kwalifikacje. W przypadku tego tytułu ubezpieczenia ustawodawca przewidział trzy progi minimalnej możliwej do zadeklarowania podstawy wymiaru składki. Bazowy, w kwocie odpowiadającej 60\% prognozowanego przeciętnego wynagrodzenia miesięcznego przyjętego do ustalenia kwoty ograniczenia rocznej podstawy wymiaru składek. Próg obniżony w kwocie $30 \%$ minimalnego wynagrodzenia dla osób rozpoczynających działalność oraz indywidualnie ustalana składka, w przypadku osób prowadzących działalność gospodarczą na mniejszą skalę. Objęcie obowiązkiem ubezpieczenia z działalno- 
ści pozarolniczej gwarantuje przedsiębiorcy ryczałtowo określoną składkę minimalną, której wysokość jest niezależna o wyniku ekonomicznego. Przedsiębiorcy osiągający wyższe przychody, opłacając składkę minimalną, zyskują dodatkowy kapitał na rozwój działalności, a ponadto możliwość doubezpieczenia ryzyka starości lub inwalidztwa za pomocą dostępnych form ubezpieczenia gospodarczego.

Warto zaznaczyć, że ustawodawca objął osoby prowadzące działalność pozarolniczą licznymi preferencjami nie tylko w ubezpieczeniu społecznym, ale także w ubezpieczeniu zdrowotnym, gdyż zgodnie z art. 81 ust. 2 ustawy o świadczeniach opieki zdrowotnej finansowanych ze środków publicznych ${ }^{32}$ podstawę wymiaru składki stanowi zadeklarowana kwota, nie niższa jednak niż 75\% przeciętnego miesięcznego wynagrodzenia ${ }^{33}$. Pomimo wprowadzenia wyższej niż w ubezpieczeniu społecznym podstawy wymiaru składki, ustawodawca zachował charakterystyczny dla tej grupy zawodowej model składki niezależnej od osiąganych przychodów. Ponadto w ubezpieczeniu zdrowotnym nie wprowadzono rocznej kwoty ograniczenia podstawy wymiaru składki, tak jak ma to miejsce w ubezpieczeniach emerytalnym i rentowym, co sprawia, że za pracowników składka na ubezpieczenie zdrowotne jest opłacania od pełnego przychodu. Przyjęte rozwiązanie dodatkowo powiększa istniejącą dysproporcję obciążeń między pracownikami a osobami prowadzącymi działalność pozarolniczą. Preferencje przyznane przedsiębiorcom mają na celu przede wszystkim skompensowanie ryzyka ekonomicznego ponoszonego przez przedsiębiorców. Z tego też względu problematyczne wydaje się uznanie za przedsiębiorców samozatrudnionych zależnych. Pod tym nienormatywnym określeniem rozumieć należy osoby prowadzące działalność pozarolniczą ( $\mathrm{z}$ reguły wysokiej klasy specjalistów, a także osoby najlepiej zarabiające), mimo faktycznego wykonywania pracy w stosunku podporząakowania ${ }^{34}$, przy jednoczesnym braku ryzyka gospodarczego. Bariery, jakie tworzy Kodeks pracy, a także ograniczone ryzyko utraty zatrudnienia, sprawiają, że z inicjatywą zmiany podstawy zatrudnienia częstokroć występują sami pracownicy. Niektóre państwa starają się przeciwdziałać zjawisku nadużywania samozatrudnienia, m.in. ograniczając zakres przyznanych im ulg i zwolnien ${ }^{35}$.

32 Ustawa z 27 sierpnia 2004 r. o świadczeniach opieki zdrowotnej finansowanych ze środków publicznych, t.j. Dz.U. 2019, poz. 1373, ze zm.

${ }^{33}$ Podstawę obliczenia składki stanowi wynagrodzenie w sektorze przedsiębiorstw w czwartym kwartale roku poprzedniego, włącznie z wypłatami z zysku, ogłaszane przez Prezesa Głównego Urzędu Statystycznego w Dzienniku Urzędowym Rzeczypospolitej Polskiej „Monitor Polski”.

${ }^{34}$ Ministerstwo Finansów, Objaśnienia podatkowe z 31 stycznia 2019 r. Informacje o schematach podatkowych (MDR), s. 72, https://www.podatki.gov.pl/media/4417/ obja\%C5\%9Bnienia-podatkowe-mdr-z-dnia-31-01-2019.pdf [dostęp: 1 marca 2019 r.].

${ }_{35}$ M. Barwaśny, Minimalna stawka godzinowa dla osób prowadzących jednoosobowa działalność gospodarcza, „Gdańsko-Łódzkie Roczniki Prawa Pracy i Prawa Socjalnego” 2017, nr 7, s. 17 i n. 


\section{Konsekwencje wyboru modelu ubezpieczenia}

Model obciążenia przychodów składkami może oddziaływać na wybór podstawy zatrudnienia zarówno neutralnie (np. model jednej daniny ${ }^{36}$, model jednolitej składki na ubezpieczenie społeczne), jak i może on determinować wybór podstawy zatrudnienia (model autonomicznych obciążeń). Każdy z tych modeli ma i zalety, i wady. W modelu jednej daniny ${ }^{37}$ czy też modelu jednolitej składki na ubezpieczenie społeczne do podstawy wymiaru składki (w modelu jednej daniny podatku) wliczany jest skumulowany przychód ze wszystkich form aktywności zarobkowej. W efekcie na wybór formy aktywności zarobkowej nie wpływają zasadniczo obciążenia z tytułu ubezpieczenia społecznego i zdrowotnego. Pracodawca, zleceniodawca oraz samozatrudniony opłacają składkę w takiej samej wysokości. Obciążenia osoby samozatrudnionej są uzależnione od jej wyniku ekonomicznego (nie uzyskując przychodu, nie opłaca składki). Czynnikiem determinującym wybór podstawy zatrudnienia jest więc przede wszystkim wola stron. Ujednolicenie danin ogranicza tzw. stymulację wypychania, tj. presję płatników wywieraną na pracowników w kierunku rozpoczęcia działalności gospodarczej czy też wyboru umów cywilnoprawnych w miejsce stosunku pracy ${ }^{38}$. Zaletą modelu autonomicznych obciążeń jest możliwość wprowadzenia zróżnicowanych sposobów ustalania składki: od przychodu (pracownicy), ryczałtowego, deklarowanego (dobrowolne ubezpieczenie) oraz mieszanego (pozarolnicza działalność). Wadą przyjętego modelu jest jednak sztywność obciążeń, co może ograniczać tworzenie i prowadzenie działalności gospodarczej. W modelu tym ustawodawca, ograniczając obowiązek ubezpieczenia np. do jednego tytułu albo do wysokości minimalnego lub przeciętnego wynagrodzenia, umożliwia dopasowanie poziomu ochrony do potrzeb ubezpieczonego. Zróżnicowanie obciążeń sprawia, że to strony podejmować będą decyzję o tym, jaki zakres ochrony przyznać w ubezpieczeniu. Odpowiednio określony standard socjalny staje się elementem rynku, a przy niskiej stopie bezrobocia także źródłem pozyskiwania osób zatrudnionych. Ograniczenie wysokości składki tworzy ponadto przestrzeń dla dodatkowych systemów zabezpieczenia społecznego. Znaczenie dodatkowych form zabezpieczenia ryzyk socjalnych jest tym większe, im powszechny system ubezpieczeń jest bardziej elastyczny. Przy niskim bezrobociu ograniczają one fluktuację pracowników. Autonomia zobowiązań jest także istotna

${ }^{36}$ M. Krajewski, Obciążenia dochodów podatkiem dochodowym i składkami na ubezpieczenia społeczne i zdrowotne - w kierunku jednej daniny czy pozostawienia obecnego modelu, „Studia BAS” 2018, nr 2, s. 139 i n. [Wybrane zagadnienia reformy opodatkowania dochodów osób fizycznych i prawnych w Polsce, red. J. Kulicki].

${ }^{37}$ Jedna danina obejmuje: składkę na ubezpieczenie społeczne, składkę na ubezpieczenie zdrowotne oraz podatek dochodowy.

38 T. Lasocki, Obniżenie składek ubezpieczeniowych dla niektórych przedsiębiorców od 2019 r. - krytyka założeń ustawy, „Praca i Zabezpieczenie Społeczne” 2018, nr 9, s. 26. 
w przypadku kumulacji tytułów, gdy ubezpieczony może dokonać wyboru czy rozszerzyć ochronę, co przełoży się na wyższe świadczenia, czy też pozostać wyłącznie przy składce z jednego tytułu ubezpieczenia.

Wybór w 1999 r. modelu autonomicznych obciążeń był podyktowany celami społecznymi i gospodarczymi, tj. utrzymaniem wysokiego standardu zabezpieczenia społecznego pracowników, rozwojem przedsiębiorczości, obniżeniem wysokiej stopy bezrobocia i ograniczeniem szarej strefy. W celu realizacji podstawowych założeń utrzymano podział na nieelastyczne ubezpieczenie pracowników oraz mające służyć zwiększeniu zatrudnienia elastyczne ubezpieczenie niepracowników. Znaczna dysproporcja wysokości składek spowodowała jednak, że podmiot zatrudniający, dążąc do optymalizacji wyniku ekonomicznego, preferował niepracownicze podstawy zatrudnienia. Elastyczność niepracowniczych tytułów ubezpieczenia oznacza możliwość deklarowania składki (działalność pozarolnicza) czy też obowiązek zgłoszenia do ubezpieczenia z jednego wybranego tytułu ubezpieczenia (zlecenie). Efektem ubocznym elastyczności ubezpieczenia jest niski poziom przewidywanych świadczeń (zarówno samozatrudnionych, jak i zleceniobiorców). Zjawisko to można określić prekaryzacją ubezpieczenia niepracowniczego. Działania podejmowane przez płatników wpływają na obniżenie przychodów FUS. Wymusza to w efekcie podjęcie działań zmierzających do ograniczania optymalizacji. Zauważalną tendencję stanowi np. przenoszenie regulacji prawa pracy na umowy cywilnoprawne (np. pracę nakładczą czy umowę-zlecenia) ${ }^{39}$. Na potrzeby niniejszej publikacji można je nazwać działaniami uszczelniającymi system ubezpieczeń społecznych. Niski poziom składki na ubezpieczenie niepracownicze wraz z innymi negatywnymi zjawiskami, np. starzeniem się społeczeństwa, sprawia, że ustawodawca jest zmuszony utrzymać wysoką składkę na ubezpieczenie pracowników. Każdorazowa zmiana obciążeń pracowników, np. ograniczenie kumulacji tytułów po przekroczeniu przeciętnego wynagrodzenia czy też obniżenie rocznej kwoty granicznej do wysokości półtorakrotności przeciętnego wynagrodzenia, oznaczałaby w efekcie obniżenie przychodów FUS. Zmiany w obrębie ubezpieczenia pracowników musiałyby zostać zrównoważone poprzez zwiększenie dotacji uzupełniającej z budżetu państwa (a więc dodatkowym opodatkowaniem obywateli) lub podniesienie wysokości składek w przypadku pozostałych osób objętych ubezpieczeniem. Wobec prognoz demograficznych działania zmierzające do uelastycznienia ubezpieczenia pracowników należy uznać za niewykonalne.

Elastyczność obciążeń przedsiębiorców jest z kolei istotna w kontekście regulacji UE. Wprowadzona w rozporządzeniach o koordynacji systemów zabezpieczenia społecznego $\mathrm{UE}^{40}$ zasada podlegania ustawodawstwu jednego państwa

${ }^{39}$ D. Dzienisiuk, Skutki oddziaływania ustawodawstwa pracy na umowy cywilnoprawne w ubezpieczeniach społecznych, „Praca i Zabezpieczenie Społeczne” 2019, nr 1, s. 103.

40 Rozporządzenie Parlamentu Europejskiego i Rady (WE) nr 883/2004 z 29 kwietnia 2004 r. w sprawie koordynacji systemów zabezpieczenia społecznego, Dz.Urz. UE L 166 
wymusza konkurencję między poszczególnymi systemami. Przedsiębiorca wykonujący $\mathrm{w}$ danym państwie minimalną określoną $\mathrm{w}$ rozporządzeniach część pracy może zostać objęty ubezpieczeniem innego państwa niż Polska, co umożliwi mu opłacenie niższej składki. Zatem zbyt sztywne regulacje krajowe mogą stymulować przenoszenie działalności za granicę, a tym samym negatywnie wpływać na liczbę przedsiębiorców objętych ubezpieczeniem w Polsce.

W polskim systemie prawnym istnieje wolność wyboru podstawy zatrudnienia. Doktrynie prawa pracy nieobcy jest jednak spór o to, czy wolność tę można ograniczyć ingerencją państwa w rynek pracy ${ }^{41}$. W związku $\mathrm{z}$ tym istotne jest pytanie o granice optymalizacji obciążeń. Z punktu widzenia prawa stanowią ją przepisy Konstytucji. Art. 67 ustawy zasadniczej wprowadza obowiązek objęcia zabezpieczeniem społecznym obywateli narażonych na ryzyka: choroby, inwalidztwa i starości ${ }^{42}$. Obowiązkiem ustawodawcy jest utworzenie oraz utrzymanie takiego systemu ubezpieczeń społecznych, który pozwoli osobom niezdolnym do pracy ze względu na podeszły wiek otrzymać środki umożliwiające im egzystencję ${ }^{43}$. Poziom nakładanych na ubezpieczonego składek musi umożliwić mu nabycie świadczeń powyżej „minimum życiowego, egzystencji” ${ }^{4}$. Z drugiej strony granicę stanowi konieczność zachowania względnej równowagi co do wysokości składek (między poszczególnymi tytułami ubezpieczenia). Cechą charakterystyczną ubezpieczeń społecznych jest finansowanie świadczeń ze składek. Co prawda, nie jest zachowana równowartość składki i świadczenia, to jednak poziom minimalnej składki musi uwzględniać utrzymanie stabilności finansowej Funduszu Ubezpieczeń Społecznych.

\section{Wnioski}

Kwestia optymalizacji kosztów zatrudnienia, jak i powiązany z nią problem unikania zawierania umów o pracę, stanowią podstawową przyczynę działań interwencyjnych ustawodawcy w wielu państwach ${ }^{45}$. Problem ten jest złożony, a jakiekolwiek gwałtowne zmiany w prawie mogą prowadzić do negatywnych

z 2004 r. oraz rozporządzenie Parlamentu Europejskiego i Rady (WE) nr 987/2009 z 16 września 2009 r. dotyczące wykonywania rozporządzenia (WE) nr 883/2004 w sprawie koordynacji systemów zabezpieczenia społecznego, Dz.Urz. UE L 284 z 2009 r.

${ }^{41}$ M. Gładoch, Prawo wyboru podstawy zatrudnienia w kontekście zasady swobody prowadzenia działalności gospodarczej, „Praca i Zabezpieczenie Społeczne” 2018, nr 5, s. 2.

42 T. Lasocki, Wybrane problemy kształtowania tytułów ubezpieczeniowych w ubezpieczeniu emerytalny i rentowym, „Ubezpieczenia Społeczne. Teoria i Praktyka” 2017, nr 3, s. 62-64.

${ }^{43}$ Wyrok TK z 4 listopada 2015 r., sygn. akt K 1/14, OTK-A ZU 2015, nr 10, poz. 163.

${ }_{44}$ Wyrok TK z 19 grudnia 2012 r., sygn. akt K 9/12, OTK-A ZU 2012, nr 11, poz. 136.

${ }_{45}$ M. Kosmol, Unikanie zawierania umów o pracę (na czas nieokreślony) przez stosowanie umów cywilnoprawnych - komentarz do reformy prawa pracy w Niemczech, „Praca i Zabezpieczenie Społeczne" 2018, nr 8, s. 15 i n. 
zjawisk, takich jak zwiększenie bezrobocia czy szarej strefy. Trafne zatem wydaje się twierdzenie, że elastyczność systemu ubezpieczeń jest niezbędna dla wzrostu gospodarczego, jednakże działania ustawodawcy winny zmierzać także w kierunku ograniczenia nadużywania stosowania umów cywilnoprawnych czy samozatrudnienia, tam gdzie sposób i charakter pracy wyraźnie wskazują na konieczność zatrudniania w ramach stosunku pracy ${ }^{46}$.

Należy zgodzić się z twierdzeniem, że w systemie ubezpieczeń społecznych nieodzowne jest utrzymanie odwiecznej dychotomii między osobami świadczącymi pracę i świadczącymi usługi a przedsiębiorcami ${ }^{47}$. Ustawodawca winien jednak wyraźnie oznaczyć, jakie elementy przemawiają za odmiennym (preferencyjnym) traktowaniem osób prowadzących działalność gospodarczą. Sam wpis do ewidencji nie powinien być kryterium decydującym. Wybór formy współpracy podejmowanej przez strony powinien być determinowany przede wszystkim celami, jakie chcą one osiągnąć, a nie poziomem obciążeń publicznoprawnych ${ }^{48}$.

Z uwagi na konieczność utrzymania stabilności finansowej Funduszu Ubezpieczeń Społecznych, ustawodawca, dokonując modyfikacji obciążeń, powinien uwzględniać wpływ dokonywanych zmian na wzrost lub obniżenie przychodów FUS. Każda forma preferencji wprowadzana przez ustawodawcę będzie powodowała zwiększenie obciążeń podatkowych pozostałych osób aktywnych zawodowo lub też ograniczenie wysokości wypłacanych przez ZUS świadczeń, poprzez wprowadzanie coraz bardziej rygorystycznych kryteriów ich przyznawania.

\section{Bibliografia}

Antonów K., Finansowe aspekty ubezpieczeń, „Praca i Zabezpieczenie Społeczne” 2002, nr 11.

Bednarowicz B., „Uberyzacja zatrudnienia” - praca w gospodarce współdziałania w świetle prawa UE, „Monitor Prawa Pracy” 2018, nr 2.

Barwaśny M., Minimalna stawka godzinowa dla osób prowadzacych jednoosobowa działalność gospodarczą, „Gdańsko-Łódzkie Roczniki Prawa Pracy i Prawa Socjalnego” 2017, nr 7.

Bińczycka-Majewska T., Kumulacja i rozłączność tytułów ubezpieczenia społecznego, „Praca i Zabezpieczenie Społeczne” 2007, nr 1.

Bińczycka-Majewska T., Zbieg tytułów ubezpieczenia emerytalnego i rentowego w nowym systemie ubezpieczeń społecznych, „Praca i Zabezpieczenie Społeczne” 2000, nr 12.

Duraj T., Granice pomiędzy stosunkiem pracy a stosunkiem cywilnoprawnym - głos $w$ dyskusji, „Gdańsko-Łódzkie Roczniki Prawa Pracy i Prawa Socjalnego” 2017, nr 7.

46 P. Wojciechowski, W poszukiwaniu kompromisu wokół umów śmieciowych, „Ubezpieczenia Społeczne. Teoria i Praktyka" 2015, nr 3, s. 97-99.

${ }^{47}$ B. Bednarowicz, „Uberyzacja zatrudnienia” - praca w gospodarce współdziałania w świetle prawa UE, „Monitor Prawa Pracy” 2018, nr 2, s. 13.

${ }^{48}$ D. Dzienisiuk, Skutki, op. cit., s. 111. 
Dzienisiuk D., Skutki oddziaływania ustawodawstwa pracy na umowy cywilnoprawne w ubezpieczeniach społecznych, „Praca i Zabezpieczenie Społeczne” 2019, nr 1.

Gładoch M., Prawo wyboru podstawy zatrudnienia w kontekście zasady swobody prowadzenia działalności gospodarczej, „Praca i Zabezpieczenie Społeczne” 2018, nr 5.

Jędrasik-Jankowska I., Nowy system ubezpieczeń społecznych - wybrane problemy, „Praca i Zabezpieczenie Społeczne" 1999, nr 3.

Jędrasik-Jankowska I., Pojęcia i konstrukcje prawne ubezpieczenia społecznego, Wolters Kluwer, Warszawa 2017.

Kalina-Prasznic U., Uwagi na temat reformy ubezpieczenia społecznego pracowników, „Praca i Zabezpieczenie Społeczne” 1999, nr 1.

Konstrukcje prawa emerytalnego, red. T. Bińczycka-Majewska, Zakamycze, Kraków 2004.

Kosmol M., Unikanie zawierania umów o pracę (na czas nieokreślony) przez stosowanie umów cywilnoprawnych - komentarz do reformy prawa pracy w Niemczech, „Praca i Zabezpieczenie Społeczne" 2018, nr 8.

Krajewski M., Obciążenia dochodów podatkiem dochodowym i składkami na ubezpieczenia społeczne i zdrowotne - w kierunku jednej daniny czy pozostawienia obecnego modelu, „Studia BAS” 2018, nr 2 [Wybrane zagadnienia reformy opodatkowania dochodów osób fizycznych i prawnych w Polsce, red. J. Kulicki].

Lasocki T., Obniżenie składek ubezpieczeniowych dla niektórych przedsiębiorców od 2019 r. - krytyka założeń ustawy, „Praca i Zabezpieczenie Społeczne” 2018, nr 9.

Lasocki T., Wybrane problemy kształtowania tytułów ubezpieczeniowych w ubezpieczeniu emerytalny i rentowym, „Ubezpieczenia Społeczne. Teoria i Praktyka” 2017, nr 3.

Muszalski W., Czynniki prawa pracy ograniczajace zatrudnienia - problem dyskusyjny, „Praca i Zabezpieczenie Społeczne” 2008, nr 12.

Pędzierski A., Zmiany w zakresie podlegania ubezpieczeniom społecznym i składek na ubezpieczenia, „Praca i Zabezpieczenie Społeczne” 2003, nr 5.

Rylski M., Pracodawca jako płatnik składek za zleceniobiorców swego kontrahenta (art. 8 ust. 2 a ustawy o systemie), „Praca i Zabezpieczenie Społeczne” 2018, nr 3.

Rymsza M., Docelowy model ubezpieczeń społecznych w Polsce, „Praca i Zabezpieczenie Społeczne" 1998, nr 9.

Ustawa o systemie ubezpieczeń społecznych, red. B. Gudowska, J. Strusińska-Żukowska, CH Beck, Warszawa 2014.

Wojciechowski P., W poszukiwaniu kompromisu wokół umów śmieciowych, „Ubezpieczenia Społeczne. Teoria i Praktyka" 2015, nr 3.

ZUS, Równowaga ekonomiczna systemów emerytalnych. Współpraca w ramach Unii Europejskiej w zakresie zabezpieczenia społecznego, Warszawa 2013.

ZUS, Rocznik statystyczny ubezpieczeń społecznych 2012-2014, Warszawa 2016.

\section{Akty prawne}

Rozporządzenie Parlamentu Europejskiego i Rady (WE) nr 883/2004 z 29 kwietnia 2004 r. w sprawie koordynacji systemów zabezpieczenia społecznego, Dz.Urz. UE L 166 z 2004 r. 
Rozporządzenie Parlamentu Europejskiego i Rady (WE) nr 987/2009 z 16 września 2009 r. dotyczące wykonywania rozporządzenia (WE) nr 883/2004 w sprawie koordynacji systemów zabezpieczenia społecznego, Dz.Urz. UE L 284 z 2009 r.

Ustawa z 26 czerwca 1974 r. - Kodeks pracy, t.j. Dz.U. 2019, poz. 1040, ze zm.

Ustawa z 20 grudnia 1990 r. o ubezpieczeniu społecznym rolników, t.j. Dz.U. 2019, poz. 299.

Ustawa z 13 października 1998 r. o systemie ubezpieczeń społecznych, t.j. Dz.U. 2019, poz. 300 , ze zm.

Ustawa z 23 grudnia 1999 r. o zmianie ustawy o systemie ubezpieczeń społecznych oraz niektórych innych ustaw, Dz.U. nr 110, poz. 1256.

Ustawa z 2 kwietnia 2004 r. o zmianie ustawy o ubezpieczeniu społecznym rolników oraz o zmianie niektórych innych ustaw, Dz.U. nr 91, poz. 873.

Ustawa z 27 sierpnia 2004 r. o świadczeniach opieki zdrowotnej finansowanych ze środków publicznych, t.j. Dz.U. 2019, poz. 1373, ze zm.

Ustawa z 23 października 2014 r. o zmianie ustawy o systemie ubezpieczeń społecznych oraz niektórych innych ustaw, Dz.U. poz. 1831.

Ustawa z 6 marca 2018 r. - Prawo przedsiębiorców, Dz.U. 2019, poz. 1292, ze zm.

Obwieszczenie Ministra Rolnictwa i Rozwoju Wsi z 19 kwietnia 2018 r. w sprawie rocznej kwoty granicznej, M.P. poz. 451.

Ministerstwo Finansów, Objaśnienia podatkowe z 31 stycznia 2019 r. Informacje o schematach podatkowych (MDR), https://www.podatki.gov.pl/media/4417/objaśnienia-podatkowe-mdr-z-dnia-31-01-2019.pdf.

\section{Strony internetowe}

Https://www.krus.gov.pl/krus/krus-w-liczbach/liczba-osob-ubezpieczonych-w-kasie-prowadzacych-pozarolnicza-dzialalnosc-gospodarcza.

Https://www.krus.gov.pl/krus/krus-w-liczbach/wymiar-kwartalnych-skladek-na-ubezpieczenie-spoleczne-rolnikow.

Https://sjp.pwn.pl/szukaj/optymalizacja.html.

https://www.zus.pl/baza-wiedzy/skladki-wskazniki-odsetki/skladki/wysokosc-skladek-na-ubezpieczenia-spoleczne. 